\title{
Consumers Protection on the Musyarakah Mutanaqisah Contract of Indonesian Islamic Banking
}

\author{
Indah Purbasari ${ }^{1}$, Murni $^{2}$, Encik Muhammad Fauzan ${ }^{3}$ \\ \{indah.purbasari@trunojoyo.ac.id ${ }^{1}$, murni@trunojoyo.ac.id, ${ }^{2}$ encik.fauzan@trunojoyo.ac.id ${ }^{3}$ \} \\ University of Trunojoyo Madura, Telang Kamal Bangkalan, East Java, Indonesia ${ }^{1}$, University of \\ Trunojoyo Madura, Telang Kamal Bangkalan, East Java, Indonesia ${ }^{2}$, University of Trunojoyo Madura, \\ Telang Kamal Bangkalan, East Java, Indonesia ${ }^{3}$
}

\begin{abstract}
This paper aims to clarify the fulfilment of Islamic banking consumers' rights in Indonesia based on the Islamic banking Products Standard of Financial Services Authority and the shariah standard. The research is conducted through doctrinal studies of musyarakah mutanaqisah (diminishing partnership) contract and its applications in Indonesia. The study results that the drawback of the Financial Services Authority Standard focuses only on administrative procedures and less attentions is devoted to the consumer protection towards the guarantee of shariah compliance in the legal standing and its implementations, such as the existence of hybrid contract and less guarantee for the consumers facility to obtain a risk sharing of the financing object. Therefore, this research promotes the urgency of stipulating shariah coverage standard in the consumer protection clause.
\end{abstract}

Keywords: Consumers Protection, Musyarakah Mutanaqisah, Products Standard, Sharia Standard.

\section{Introduction}

Islamic banking has been integrated in Indonesian banking system. It is legitimized by the Indonesian Law Number 21 of 2008 on Shariah Banking law and enhanced by the blue print of Islamic Banking Development made by Indonesian Central Bank.[1] The operations of Islamic banking are also progressively built up with supporting legal standings such as Fatwa Dewan Syariah Nasional Majelis Ulama Indonesia (Resolution of National Shariah Board, Indonesian Ulama Council Resolution), Indonesian Financial Service Authority Regulation, Compilation of Shariah Economic Law.

Having developed in more than a decade in Indonesia, the Islamic banking product varies in advanced including in the field of home-financing facilities. Once, home -financing facility only used murabahah (set profit sale contract). Murabahah contract became the preference because the finances were standardized by the sale price of the object thus it made the instalment flat during the financing period. Compared to the floating rate interest in conventional banking, fixed instalments in murabahah finance possibly attract customers to apply for the home-financing facility. For Islamic banks, the positive perception of customers is significant because in dual banking system practice, they have to compete with conventional banks.[2] However, almost similar to the controversial issue on the existence of bai al inah (sale and buy back transaction) in the contract of bai bithaman ajil (differed 
payment sale) [3]. murabahah contract also arises shariah issues on the existence of aqd wakalah (giving delegation to customer to provide the object purchased) at which it shows an incapability of bank as a seller to provide the subject matter of the contract. Other issues comes up in relation to very high mark-up prices due to a long period of financing and discounts in early settlements [4].

Therefore, aqd musharakah mutanaqisah (diminishing partnership contract) was created as the alternative contract for home-financing and as the solution to reduce the controversial problem occurred in murabahah or bai bithaman ajil [5]. Since the aqd musharakah mutanaqisah lauched in 2007, based on Shariah Resolution in Islamic Finance Bank Negara Malaysia and in 2008, due to Fatwa Dewan Syariah Nasional Majelis Ulama Indonesia (Resolution of National Shariah Board, Indonesian Ulama Council) on Musyarakah Mutanaqisah, the utilizations of the aqd (contract) diverse in In Malaysia and Indonesia. In Malaysia, most Islamic banks replace bai bithaman ajil into aqd Musharakah Mutanaqisah, tawwaruq or Ijarah muntahia bittamilk. Meanwhile, Indonesia, murabahah remains the first option for a house financing contract. Only four Islamic banks in Indonesia use aqd musharakah mutanaqisah for home financing namely Bank Muammalat Indonesia, Bank Mega Sharia, Panin Bank Sharia, Maybank Syariah.[6]

It encourages studying more curious on the consumers protection in shariah perspective, especially relates to the aspects of consumers' right in the adjustment price, legal documents and the position of consumer as partner aqd musyarakah mutanaqisah (diminishing partnership contract) of Indonesian Islamic banking. In other word, the research question refers to the adequacy of existing laws relating to aqd musharakah mutanaqisah in Indonesia in the matter of consumer protection in shariah perspective. Consumer protections in Indonesia refer to Indonesian Law Number 8 of 1999 on Consumer Protection, Indonesian Law Number 21 of 2011 on Financial Services Authority and the Islamic banking products standard of Otoritas Jasa Keuangan (translated as Financial Services Authority, in Indonesian term usually shortened as OJK). Among the whole legal standings, it also brings up the essential question due to the shariah point of view considers the guarantee the shariah compliance in implementation of the contract. Hopefully, the result of the study can be reference to draft shariah standard for consumer's protection in the Islamic banking products especially in the products which apply the contract musharakah mutanaqisah (diminishing partnership). 


\section{Methods}

\subsection{Research type and approaches}

This study is categorized as a doctrinal research. It is a type of library research which purposes to clarify "the principles, provisions, concepts, theories or working of certain laws and legal institutions, to evaluate the effectiveness of the law" and to recommend new paradigm of suggested norms [7]. As such, this research focuses on evaluating the adequacy of the existing laws and the sharia paradigm of consumer protection on musyarakah mutanaqisah. It applies the legislative and keyword/fact approaches [8]. The keywords and factual approach to be analysed are musyarakah mutanaqisah contracts and consumers protection. Then, the legislative approach is used to answer the problematical issues on the legal standing of musyarakah mutanaqisah and its implementation.

\subsection{Primary and secondary materials of the research}

The primary materials of the research consist of the ruling of shariah principle in Indonesian Law Number 21 of 2008 on Islamic Banking, consumers' rights and their protection scopes in Indonesian Law Number 8 of 1999 on Consumer Protection and Indonesian Law Number 21 of 2011 on Financial Services Authority, OJK (Financial Services Authority) Standard for Islamic Banking Products for aqd musyarakah mutanaqisah, Fatwa Dewan Syariah Nasional Majelis Ulama Indonesia (Resolution of National Shariah Board, Indonesian Ulama Council) Number 73/DSN-MUI/XI/2008 on Musyarakah Mutanaqisah. The secondary materials of this research are taken from credible references such as, books, journal, previous study, shariah standards from The Accounting and Auditing Organization for Islamic Financial Institutions (AAOIFI) and Shariah Resolution in Islamic Finance Bank Negara Malaysia (Central Bank of Malaysia) and documents related to Islamic banking contract of aqd musyarakah mutanaqisah and consumer protection. They are accessed from a library study and browsing materials from official website of $O J K$ (Financial Services Authority) of Indonesia, National Shariah Board of Indonesian Ulama Council, The Accounting and Auditing Organization for Islamic Financial Institutions (AAOIFI), Bank Negara Malaysia (Central Bank of Malaysia), Mendeley, research gate and open access journals.

\subsection{Collecting Materials and Analyzing Methods}

Both primary and secondary materials are collected through library research and browsing online journals, documents and information. The selected materials put in reference manager of Mendeley in order to be analysed through a deductive reasoning. A deductive reasoning is an analysis procedure beginning from the general concepts or theories and how they work on a concrete subject matter and to formulate a specific conclusion.[9] The general concepts regard to the norm of the aqd musharakah mutanaqisah or diminishing partnership in shariah perspective and Indonesian legal standing, the concept and rule of consumer right and protection in Indonesia. They are analysed their synchronization with the practice of the consumer protection of the aqd musharakah mutanaqisah. The outcome is a suggestion on the legal standing to cover the shariah view on consumer protection of the aqd musyarakah mutanaqisah. 


\section{Discussion}

\subsection{General concepts of musyarakah mutanaqisah}

Musyarakah mutanaqisah derives from the principle musyarakah (capital joint venture profit and loss sharing). It is usually practiced in general investment. Two parties or more agree to be partner in conducting business. They join capital and consent the profit and loss sharing. Meanwhile, Musyarakah mutanaqisah has a specific characteristic compared to the original contract, musyarakah. According to Sharia standard of AAOIFI, Musyarakah mutanaqisah defines as a partnership between two parties or more in which one particular party promises to buy another party's asset in stages until he completely own the asset [10].

Legitimacy of musyarakah mutanaqisah is based on Quran Surah Shad verse 24, translated "truly many are associates (in business) who wrong each other: not so for those who believe and work deeds of righteousness..."[11] The term "associates" in the verse regards to partnership. It rules the permissibility of partnership in commercial transaction but prohibits to the oppressing action in partnership. In other words, this Quranic verse encourages Muslim to be fair, equal and honest in business partnership. Besides, the hadith narrated by Abu Daud from Abu Hurairah, the Prophet Muhammad PBUH said that Allah SWT Exalted be He, says, 'I am the third of the two partners (i.e Allah is with them, taking care of, keeping, supporting, and sending down blessing upon their trade) as long as one of them does not cheat the other. But, when he cheats him, I depart from them [11]." It explains the validity of partnership and stress on the loyalty among the parties and prohibition of cheating [12].

The original rule of musyarakah mutanaqisah follows the element of musharakah itself namely, sharik (contractual parties/partners), capital venture (in cash), transparancy in nisbah (portion or ratio) of profit and loss e of sharing, the existence of ijab (offer) and qabul (acceptance). It is interpreted extensively that musyarakah mutanaqisah consist of sharik (partner) namely parties included in this contract. The characteristics of hissah (portion of partner in asset belonging) is musha'. Musha' means that portion of partner in asset belonging cannot be determined physically but justified in value.[13] Musyarakah mutanaqisah is classified as a type of contractual partnership. Jurists agree on two types of partnership namely shirkah al-aqd (contractual partnership) and (shirkah al-milk (holding). Shrikah al-aqd occur as the result of the contractual agreement between to two parties. It usually conducts in business enterprise. Each party joins in capital venture and consents the profit and loss sharing. Shirkah al-milk (holding partnership) is joint ownership originated from inheritence or wills. The process of inheritance or wills creates the transfer of ownership of the tangible asset. Later, the parties as the owners of the tangible asset came from inheritence process agree to share the asset and return. It comes naturally without contractual agreement [14].

\subsection{Home Financing Based On the Contract of Musharakah Mutanaqisah (Diminishing Partnership)}

Legitimacy of musyarakah mutanaqisah in Indonesian Islamic banking is based on Indonesian Law Number 21 of 2008 on Islamic Banking, section 19c. It rules the business enterprise of Islamic banking includes financing based on profit and loss sharing contract, musharakah (capital joint venture profit and loss sharing partnership) and mudharabah (trustee profit sharing partnership). Musyarakah mutanaqisah is derivative contract of musharakah. Further, the shariah standard of aqd musyarakah mutanaqisah is stipulated on Fatwa Dewan Syariah Nasional Majelis Ulama Indonesia (Resolution of National Sharia Board, Indonesian Ulama Council) Number 73/DSN-MUI/XI/2008 on Musharakah 
Mutanaqisah Herein, musyarakah mutanaqisah is syirkah (partnership) at which the asset or capital ownership of one party diminishes gradually due to the purchase of the other partner. [13]. The practical steps of musyarakah mutanaqisah describe in the following:

1. Customers apply the home financing based on the contact of musyarakah mutanaqisah. For this purpose, customers need to clarify the supporting document of the purchased property (house) and the capability of the customer to pay.

2. Islamic banking approves the customer's application of home financing by using the contract of musyarakah mutanaqisah.

3. Bank and customer consent the amount of financing and shares the house ownership during the period of payment.

4. Customers agree to pay his portion, for instance, $10 \%$ of the price and bank supplies $90 \%$ to acquire the asset.

5. Customer agrees to pay in particular tenure (usually in a long-term financing 10-15 years). It contains the principal price of the house and monthly rent as the bank portion.

6. The income derived from the project (monthly rent) is shared between the bank and the customer regarding to their capital contribution (90:10). Bank will credit the customer's share to a specific account with the bank for the purpose of buying the bank's share [15].

7. The ratio of bank ownership decreases due to the customer instalment and vice versa.

There are three issues on the application of musyarakah mutanaqisah, those are related to shariah, legal documents and operational.[16] The main issue in shariah and legal document is the existence of a hybrid contract in musyarakah mutanaqisah. Herein, there are indications of a disharmony between the law in book and law in action. A discrepancy occurs when banks assigns all payment obligations for fees to the customer. Besides, accounting standards for musyarakah mutanaqisah has yet been available [17]. The accounting still follows the standard of general musharakah (partnership) agreement.Those appears the issue of consumer protection relates to the spiritual rights of the consumers toward the sharia compliance accomplishment.

\subsection{Consumer Protection In Indonesian Islamic Banking}

Consumer simply defines as the user of particular product or service. They can be classified into the users who may take benefit during the process of production (raw material, agency/distributor) or the user of the final product [18]. The base rights of consumers consist of the right of safety, the right to be informed, the right to choose, the right to be heard [19]. Indonesian Law Number 8 of 1999 on Consumer Protection ruled balance position in the producer's obligation and also the consumer's right. Indonesian Customer Law also details the rights of consumers in section 4. They involve right of consumer to get the comfort and safety of the offer goods and/or service, right to choose and get the appropriate price and condition of the product and/or service, right to accept clear and fair information, right to be heard, right to get advocacy, protection and the effort of dispute settlement, right to get consumer protection education, right to get compensation. These rights provide balance obligations also between consumers and producers to create better condition in trade.

The current institution which has authority to provide consumer protection for financial institution in Indonesia is called Otoritas Jasa Keuangan (OJK) translated as Financial Services Authority of Indonesia. One of the OJK functions in section 4c Indonesian Law Number 21 of 2011 on Financial Authority Services is consumer protection of financial institutions including Islamic Banking. Sections 28-30 of the law declare OJK authorities to prevent unlawful acts of finance institutions which impact to the consumers loss, provide 
hotline services for accommodating consumers complain and facilitating negotiation and providing advocacy for the financial institution consumers who suffer loss.

Later, Financial Services Authority of Indonesia or OJK launched Product Standard of Musyarakah and Musyarakah Mutanaqisah. It orders Islamic banks to give detail information for all product and contract. The details consist of name of the products, its types, benefits and risks, terms and conditions for the consumers, rights and obligations, procedure for accessing the products, fees or charges, duration of the products, complain procedures and the products launching. Finance institutions are compulsory to make sure that consumers figure out their clarity of the products, their rights and obligations and put their sign above the stamp. The standard commands the usage of personal data of the consumers for internal bank necessities and due to the law, assure that it is classified as a secret document. The share of consumer personal data to others must be followed by clear information from the bank about the purposes and their consequences and permitted by the consumers, proved by the signature above the stamp. Besides, consumers enable to send complain for the misused of personal data and access the facility of dispute settlements due to the law [16]. The standard shows that it has yet ruled the shariah compliance including the clause of consumer protection. Meanwhile, the previous study was conducted by Rofah Setyawati et. al argued that shariah compliance guarantee can be also part of consumer right due to spiritual right of the consumers [20].

\subsection{Consumer Protection in the Product of Musyarakah Mutanaqisah}

The above discussion describes the general aspects of consumer protection in Islamic banking and the importance of involving shariah compliance as one the aspect of consumer's protections. In other words, the protection should be included both shariah and legal matters. Three recent problems regarding to consumers protection in the product of musyarakah mutanaqisah are clarified as follows:

The first issue is a hybrid contract in adq musyarakah mutanaqisah. The drafting of musyarakah mutanaqisah in Indonesian Islamic banking differs from the legal documentations of it in Malaysia. Malaysian Islamic banking separates clearly the legal document of musyarakah mutanaqisah into six documents, namely document 1: wa'ad (promise), document 2: Letter of Offer, document 3: Musyarakah Mutanaqisah Facility Agreement, document 4: Sale and Purchase, document 5: Ijarah Leasing Agreement, document 6: Trust Deeds, document 7: Letter of Undertaking or Service Agency Agreement. The more legal documentations are needed, the more charges should be paid by the customer. It certainly becomes the customer's burden without any sharing from the bank as partner. [21] Meanwhile, Fatwa Dewan Syariah Nasional Majelis Ulama Indonesia (National Shariah Board, Indonesian Ulama Council Resolution) Number 73/DSN-MUI/XI/2008 on Musharakah Mutanaqisah arranges the separation of the clause of wa'ad (promise of purchase/ sale) and the avoidance of ta'aluq (two or three more contracts in one goods). In a practice, there is only a single contract document but there is a clause which indicates separated agreements. Legal documentation of musyarakah mutanaqisah in Indonesian Islamic banking only consist three documents namely the contract of musyarakah mutanaqisah, documentation of legal status of asset and the table of payment [23]. Commonly, the Indonesian Islamic finance institutions prefer to make simple legal documentation of the contract document. It relates to the efficiency of administrative fee. Regarding the concept of consumer protection, the efficiency of administrative fee may guarantee the right of consumer to get the appropriate price value but it lacks the clearness in shariah point of view. The clause of promise, partnership and leasing are included in one legal 
documentation of contract. It may appear the confusion or unclear information in the legal documentation. It may also affect to the right of consumers to get clear information.

The second is the adjustment price. OJK standard forbids the clause of fixed amount in the profit and loss sharing of the rent clause.[16] It means that musyarakah mutanaqisah contract gives a bank opportunity to conduct adjustment price periodically. Based on the information of the Islamic banking officers and consumers, it creates the customer's worry that Islamic bank may increase the rate of monthly rent highly. The multiple increasing of monthly rent ever happened as the impact of releasing of bank officer. It affects to the withdrawing the home financing facility. Islamic banking increases the rental price. It shows the possibility of the minor position of consumer in the case of adjustment price.

The third problem, although bank and consumers are partners which have an equal position in contract, practically, banks provides consumers with standard contract. Standard contract only gives the customer choice "take it or leave it. Syirkah or partnership should be built based on mutual consent. However, standard contract creates the consumer in a lower bargaining position. It is encouraged by Ali, et al who states that it is unfair to apply standard contract in musyarakah mutanaqisah. [22]

The forth issue is liability of the customer toward damage of the asset during the period of financing. Product standard of OJK only recommends both parties to conduct negotiation.[16] In practice, Indonesian Islamic banking put the damage risk to the customer. The customer price has been included insurance for property injured. However, the spirit of musyarakah mutanaqisah is sharing ownership. It means that the risk of injured property should also be shared due to the principle of musyarakah is profit and loss sharing. According to Idris, the contract of musyarakah mutanaqisah in Malaysia allows to put the guarantee of major damage (for instance, because of disaster) of the property [24]. In other word, it enables to share risk in major damage of the financed property. Thus, it implies the partnership between bank and its customer in term of customer protection on property damage.

\section{Conclusion And Recommendations}

The discussion above concludes that the OJK standard for consumers protection of musyarakah mutanaqisah exclude the guarantee of the fulfilment of the shariah compliance of the contract whereas it is included in the consumers right. Regarding to the shariah point of view in accomplishing consumers protection, the contract of musyarakah mutanaqisah in Indonesian Islamic banking should consider the four major issues of shariah compliance of the hybrid contract, an a possibility of conducting adjustment rent price of object, an equal position of consumer in negotiation and the standard contract made by the bank, and a tendency of burdening a damage risk during the rent period of financing to the consumers. It shows the attention of Islamic banking to the aspect of customer protection.

The recommendation for OJK standard relates to the significance to put the clause of the guarantee of the accomplishment of shariah compliance as part of consumer's protection. Besides, the OJK standard and Indonesian Islamic banking need to:

a. Draft the clear separation of legal documentation of musyarakah mutanaqisah. The document of wa'ad (promise), shirkah (partnership) and ijarah (leasing) should be in particular documentation, not only different clause. It will give clear information as the right of the consumers and fulfil the shariah compliance. 
b. Make standard procedure for an adjustment price and determine the term of condition which enables to held adjustment price. It should not occur in short term to avoid the perception of floating rate and the determination of the price should consider the capability of customer to pay it. It may keep the customer right in getting appropriate price.

c. Although Islamic banking applies standard contract, it should be followed with the preface discussion, bargaining price and share not only determined by the bank. Bank should give the opportunity of the bank to clarify and to be heard. It shows the equal position between bank and its customer.

d. Indonesian Islamic banking should put the clause on damage risk. Islamic banking should consider the sharing risk of major damage to guarantee the customer protection.

\section{References}

[1] Bank Indonesia, "Islamic banking in Indonesia in brief." https://www.bi.go.id/en/ssk/syariah/Contents/Default.aspx (accessed Sep. 02, 2020).

[2] F. F. H. Aam Slamet Rusydiana, "Islamic Banking Selection Criteria: Case in Indonesia Using Analytic Network Process," Economica: Jurnal Ekonomi Islam20, vol. 10, no. 1, pp. 165-188, 2019, doi: https://dx.doi.org/10.21580/economica.2019.10.1.2846.

[3] K. H. M. Subky, J. Y. Liu, M. M. Muhammad Muzzammil, Z. F. Mokhtar, and A. Faizrakhman, "The Implication of Musharakah Mutanaqisah in Malaysian Islamic Banking Arena: A Perspective on Legal Documentation," International Journal Of Management and Applied Research, vol. 4, no. 1, pp. 17-30, Feb. 2017, doi: 10.18646/2056.41.17-003.

[4] A. F. Yustiardhi, M. Aulia, and R. O. Permatasari, "Islamic Contracts for Home Financing: A Comparative Analysis," International Journal of Management and Applied Research, vol. 6, no. 4, 2019, doi: 10.18646/2056.64.19-030.

[5] M. N. Mohamed Imtiyaz, S. Kassim, and N. Z. Harun, "Perceived fairness in islamic home financing: Comparison between Al-Bay' Bithaman Ajil and Musharakah Mutanaqisah partnership contracts," Planning Malaysia, vol. 15, no. 4, 2017, doi: 10.21837/pmjournal.v15.i4.315.

[6] Muh Turizal Husein, "Telaah kritis akad musyarakah mutanaqisah," Al Maal : Journal of Islamic Economics and Banking, vol. 1, no. 1, pp. 79-88, 2019, doi: 10.31000/almaal.v1i1.1775.

[7] A. Yaqin, Legal research and writing. Kelana Jaya, Selangor Dahrul Ehsan, Malaysia: Lexis Nexis, 2007.

[8] T. Hutchinson, Research and writing in law. Sydney, Australia: Thomson Legal\&Regulatory, 2006.

[9] W. L. Neuman, Social research method: qualitative and quantitative approaches. Boston, USA: Pearson, 2006

[10] The Accounting and Auditing Organization for Islamic Financial Institutions, Shari'ah Standards. Manama, Bahrain: King Fahd National Library, 2016.

[11] A. Y. Ali, The Holy Quran Translation. .

[12] S. Al-Fawzan, A Summary of Islamic Jurisprudence Volume 2. Riyadh, Saudi Arabia: AlMaiman Publishing House, 2005.

[13] Fatwa Dewan Syariah Nasional Majelis Ulama Indonesia Nomor 73/DSN-MUI/XI/2008 tenting Musyarakah Mutanaqisah. Jakarta, Indonesia: Dewan Syariah Nasional Majelis Ulama Indonesia, 2008.

[14] W. Al-Zuhayli, Financial Transaction in Islamic Jurisprudence Volume 1 (tr). Damascus: Dar Al-Fikr, 2007. 
[15] Shariah Advisory Council, Shariah Resolutions in Islamic Finance, Second. Kuala Lumpur: Bank Negara Malaysia (Central Bank of Malaysia) https://www.bnm.gov.my/microsite/fs/sac/shariah_resolutions_2nd_edition_EN.pdf, 2010.

[16] Otoritas Jasa Keuangan, Standar Produk Musyarakah dan Musyarakah Mutanaqisah. Jakarta, Indonesia: Departemen Perbankan Syariah Otoritas Jasa Keuangan, 2016.

[17] N. Basyariah, "Analisis Implementasi Pembiayaan Musyarakah Mutanaqishah Pada Perbankan Syariah di Indonesia," Muqtasid: Jurnal Ekonomi dan Perbankan Syariah, 2018, doi: 10.18326/muqtasid.v9i2.120-133.

[18] A. Atsar and R. Apriani, Buku Ajar Hukum Perlindungan Konsumen di Indonesia. Sleman Yogyakarta: Deepublish, 2019.

[19] Zulham, Hukum Perlindungan Konsumen. Jakarta: Kenyan, 2016.

[20] R. Setyowati, I. Purbasari, and E. M. Fauzan, "Consumers spiritual rights in the islamic banking dispute out of court settlement in Indonesia," Journal of Social Studies Education Research, vol. 9, no. 4, 2018, doi: 10.17499/jsser.64249.

[21] M. Z. Md Nor, "Legal Documentation for Islamic Finance Facilities,” Kuala Lumpur, Malaysia, 2010 .

[22] S. A. M. Ali, R. Hassan, and A. A. Othman, "Inadequacy of Consumer Protection from Unfair Contract Terms in Musharakah Mutanaqisah Home Financing in Malaysia," Journal of Islamic Finance, vol. 6, no. Special Issue, 2017, doi: 10.12816/0047351.

[23] Bank Indonesia, Draf Kontrak Musyarakah Mutanaqisah. Jakarta, Indonesia: Bank Indonesia, 2010.

[24] S. M. Idris, "Syariah Risk in Musyarakah Mutanaqisah Home Financing Contract in Malaysia," International Journal of Academic Research in Business and Social Sciences, vol. 8, no. 5, Jul. 2018, doi: 10.6007/IJARBSS/v8-i5/4226. 